$\begin{array}{lc}\quad \text { Pulse } & \begin{array}{c}\text { Selenium content } \\ \text { (mgm./100 gm. dry) }\end{array} \\ \text { P. radiatus } & 2 \cdot 5 \\ \text { P. sativum } & 1 \cdot 2 \\ \text { C. arietinum } & 5.0 \\ \text { L. esculenta } & 2 \cdot 3 \\ \text { L. sativus } & 22 \cdot 9\end{array}$

Selenium has been given intraperitoneally to the monkey beginning with a dose of $500 \mu \mathrm{gm}$. and ending with $820 \mu \mathrm{gm}$. daily. In a period of eightyfour days, there were thirty-six blank days and forty-eight injections of a total of $31.23 \mathrm{mgm}$. selenium. After forty-one injections, extensor plantar (upturning of the hallux on stimulation) was first observed. The first sign of abolition of abdominal reflex was observed after forty-three injections. Flaccidity, the sign of ablation of area $4^{3}$, was also present. The upturned hallux after selenium administration in the monkey is very significant. The sign is produced in man and anthropoids when the pyramidal tract is interrupted; in the monkey, only when the entire cerebral hemisphere is removed ${ }^{4}$. Evidently selenium has not only caused degeneration of the pyramidal tract but has also produced more widespread lesions in the cerebral cortex. After the total dose of $31.23 \mathrm{mgm}$. of selenium, alkaline serum phosphatase was found to be increased to $90 \mathrm{King}$ and Armstrong units ${ }^{5}$, as compared to 14 units in the normal animal. Rudra and Bhattacharya ${ }^{6}$ had previously observed that alkaline serum phosphatase is raised in lathyrism.

One of the mechanisms of action of selenium is by interference with methionine metabolism. In lathyrism patients who are still consuming the vetch pea, the methionine excretion falls to a fifth of the normal, the excretion rising to normal as soon ais other pulses are substituted for the vetch pea?. Very early anorexia and gastrointestinal disorders are probably due to a disturbance in aneurin metabolism. Marked dermatitis may be due to some disorder in biotin utilization, since biotin is interrelated with fatty acid metabolism. We interpret these observations as due to selenium competing with sulphur. There is some indirect evidence that in lathyrism (due to selenium intoxication) the transmethylation process may be interfered with. Gillis and Norris ${ }^{8}$ report that vitamin $B_{12}$ helps the trans-methyla tion process. Rudra et al. ${ }^{\circ}$ observed that motor neurone lesions in lathyrism patients are healed (extensor plantar becomes flexor; abdominal reflex) when methionine is given with vitamin $\mathrm{B}_{12}$, while methionine given alone has no effect.

We are of opinion that selenium may interfere with enzyme systems requiring the sulphydryl or sulphamethyl groups for activity. The investigation is being continued.

We are indebted to the British Drug Houses, Ltd., for the gift of sodium selenite.

Department of Medical Chemistry,

$$
\text { M. N. RUDRA }
$$

Darbhanga Medical College,

$$
\text { Laheriasarai, Bihar. }
$$

April 24.

${ }^{1}$ J. Assoc. Off. Agric. Chem., 24, 363 (1941).

"Rev. Clin. Espanola, 8, 244 (1943).

${ }^{3}$ Rés. Pub. Assoc. Nerv. Ment. Dis., 13, 158 (1934).

'J. Nerv. Ment. Dis., 96, 493 (1942).

"Can. Med. Assoc. J., 31, 376 (1934); 32, 379 (1935).

${ }^{\circ}$ Lancet, 1, 688 (1946)

${ }^{3}$ Curr. Sci., 21, 99.

S. Biol. Chem., 179, 487 (1949).

'Indian Med, Gaz., No. 3 (March, 1952) ; J. Asiatic Soc. Bengal $82,89$.

\section{Toxicity of Dextran in Rats}

THE anaphylactoid reaction caused by dextran in rats has recently been studied by several investigators $^{1-3}$. We have found that after intradermal injections of dextran dissolved in physiological saline (in rats), Menkin's intravenous dye test ${ }^{4}$ shows a seepage of dye into the wheals when the concentration of commercial dextran (Macrodex, Pharmacia Inc.) is at least $10 \mu \mathrm{gm} . / \mathrm{ml}$. Moreover, it has been found that dextran preparations with highly branched molecular chains are more toxic than those with relatively unbranched chains. Dextran fractions of an average molecular weight of 10,000 cause a positive dye test only in concentrations of about $10 \mathrm{mgm} . / \mathrm{ml}$. Sulphuric acid esters of dextran ${ }^{5}$ do not cause increased capillary permeability. We have confirmed the previously reported increase in hæmatocrit values after intravenous injection of dextran ${ }^{3}$, and found that it is more or less completely prevented by antihistaminics, local anæsthetics and pretreatment with cortisone in high doses. The most potent inhibitor, however, is alloxan intravenously in a subdiabetogenic dose. 2,3-Dimercaptopropanol injected $30 \mathrm{~min}$. before dextran has an inhibitory effect only in some experimental series. The factors causing these variations in the 'antiphlogistic' effect of $B A L$ are under study.

\section{T. EDLUND}

B. LÖFGREN

Institute of Pharmacology,

L. VÄLI

University of Uppsala. Jan. 2.

Morrison, J., Bloom, W. T., and Richardson, A. P., J. Pharmacol. Exp. Ther., 101, 27 (1951).

Yoorhees, A. B., Baker, H., and Pulaski, E. J., Proc. Soc. Exp. Biol. and Med., 76, 254"(1951). 3orrison, J. L., Richardson, A. P., and Bloom, W. L., Arch. Int.
Pharmacodyn., 88, 98 (1951).

'Menkin, V., J. Exp. Med., 50, 171 (1929).

s Grönwall, A., Ingelman, B., and Mosiman, H., Upsala Lakareforenings Forhandlingar, 66, 397 (1945).

Viability of Conispiculum guindiensis in Calotes versicolor Preserved in Formalin

Several specimens of Calotes versicolor (a garden lizard) were collected from gardens in Guindy near Madras, during March 1949. Blood, exuding from their cut tails, was examined for filarial infection. Six calotes found positive with microfilariæ of $C$. guindiensis were killed by the use of chloroform. Before preservation in formol-saline (one part of commercial formalin to four parts of normal saline) a 2-in. slit was made in the abdominal wall to open it. The specimens were brought to Delhi for demonstrating the adult worms in situ. In one specimen, which was dissected fourteen days later, although some degree of putrefaction had taken place, viable filarial worms were seen. Some of the adult female worms contained ova which stretched out to typical microfilarial forms. Similar findings were observed in the remaining calotes dissected at weekly intervals. The last two calotes were dissected in the sixth week of preservation. Temperature during that period ranged from $97 \cdot 0^{\circ} \mathrm{F}$. maximum to $51 \cdot 0^{\circ} \mathrm{F}$. minimum.

Similar results were observed in another batch of four calotes caught from the same area during March 1951. In yet another lot of four calotes, commercial formalin was used as a preservative, but all worms 